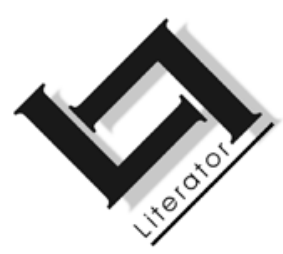

\title{
Die aantrekkingskrag van die see
}

\author{
I. Gertenbach
}

Departement Afrikaans-Nederlands

Universiteit van Kaapstad

KAAPSTAD

E-pos: ib_subed@yahoo.co.uk

\begin{abstract}
The magnetism of the ocean

This article compares the use of oceanic symbolism in the poetry of Karin Boye, Ingrid Jonker and Sylvia Plath. Freud's "oceanic feeling" is described and contrasted with Jung's theory of the "great mother". According to Jung, the "great mother" is the unconscious which is represented by water. All these elements are discussed in the poems and compared to each other in order to gain a better understanding of the poetry. Although "death" (drowning) in the ocean appears to point to new life, it ends in unification with the archetypal mother. This liberates the poets symbolically, but not physically.
\end{abstract}

\section{Opsomming}

\section{Die aantrekkingskrag van die see}

Hierdie artikel vergelyk die seesimboliek in die poësie van Karin Boye, Ingrid Jonker en Sylvia Plath. Freud se "oseaanbelewenis" word beskryf en teenoor Jung se teorieë van die "groot moeder" geplaas. Die "groot moeder" is volgens Jung ook die onbewuste, wat deur middel van water voorgestel word. Al hierdie elemente word in die gedigte bespreek en teenoor mekaar geplaas om die werklike betekenis van die gedigte na te speur. Al lyk dit asof die "dood" (verdrinking) in die see op nuwe lewe dui, is die uiteinde daarvan eintlik vereniging met die argetipiese moeder. Dit verlos die digters dus simbolies, maar nie fisies nie.

\section{Inleiding}

Die sielkundiges Sigmund Freud en Carl Gustav Jung het ses jaar lank 'n noue vriendskap gehad totdat Jung se Transformations and 
symbols of the libido (Stevens, 1994:22) in druk verskyn het. Hierdie boek het gelei tot 'n breuk tussen hulle, omdat Freud gemeen het elkeen het sy eie, unieke, persoonlike onbewuste, terwyl Jung van mening was dat dit deur die mensdom gedeel word. Die kern van die mens se kollektiewe onbewuste is volgens Jung die self, omring deur soortgelyke argetipes. 'n Mens word met argetipes gebore; oerbeelde wat al eeue lank van ouer na kind oorgedra word (Jung, 1959:5). Die argetipe kry 'n persoonlike vorm of kleur, wat Jung 'n kompleks noem, aangesien mense in verskillende omstandighede (land, tydperk, ras, ens.) gebore word (Stevens, 1994:48). Argetipes sluit die anima/animus, die skaduwee, die wyse ou man en die groot moeder in.

Die doel is van hierdie artikel is om die gebruik van die verlange na die see, op 'n simboliese vlak, deur die digters Karen Boye, Ingrid Jonker en Sylvia Plath te vergelyk. Volgens Jung is die moederlike betekenis van water (seë, riviere, en dies meer) een van die duidelikste interpretasies van 'n simbool in die mitologie (Jung, 1956:218) en hier word dit in poësie nagespeur. Die sielkundiges se standpunte hieroor word ook teenoor mekaar geplaas.

\section{Oseaanbelewenis}

Freud noem die begeerte na eenwording met die see 'n "oseaniese ervaring" of "oseaanbelewenis" (Strachey et al., 1961:64; Van Wyk, 1984). Hiermee verwys hy na die mens se simboliese drang om 'n grenslose eenheid met die heelal te vorm (Milner, 1988:418). Dit is simbolies daarin dat dit nie 'n werklike drang na hergeboorte is nie, maar 'n simbool, soos die see, wat dieselfde geborgenheid as die baarmoeder bied. Hierdie gevoel kan teruggevoer word na die embrionale stadium van die mens se ontwikkeling. Die ervaringswêreld binne die baarmoeder is soos ' $n$ oseaniese belewenis, waar 'n mens 'n byna grenslose eenheid met die moeder beleef. Die kind en die moeder is nie identies nie, maar vanweë die "watermassa" waarin die baba sweef, voel dit nie asof daar 'n grens tussen die twee is nie. Op hierdie manier is die kind se identiteit één met dié van die moeder. Verder ervaar 'n mens nie honger, dors of ongemak binne die baarmoeder nie, maar na geboorte is dit belangrik dat die baba gewoond raak aan sy "geskeidenheid" (separateness). Dit beteken dat die baba bewus moet word van homself as ' $n$ wese met 'n eie identiteit, eie behoeftes en sensasies (Gertenbach, 1997).

Ten spyte van hierdie vurige verlange na die oseaan, is die verlange met vrees gevul aangesien die persoon deur sy eenheid met die see (of baarmoeder) sy eie identiteit verloor. Sodra hierdie vrees oorkom 
word, is dit weer moontlik dat die individu se persoonlikheid verder kan ontwikkel. Milner (1988:29) bespreek in hierdie verband 'n pasiënt wat 'n dringende begeerte gehad het om deur haar ma vasgehou te word, maar tegelykertyd daaroor angsbevange was. Al het sy dus na die liefde van 'n moeder verlang, was sy bang sy sou verdrink, of deur haar moeder versmoor word.

Al het Freud hierdie gevoel omskryf nadat iemand 'n brief daaroor aan hom gestuur het, glo hy nie self daaraan nie, "I cannot discover this 'oceanic' feeling in myself" (Strachey et al., 1961:65). Jung se antwoord hierop is eenvoudig, "You can only say that you have never had such an experience, whereupon your opponent will reply: 'Sorry, I have.'.' (Steele, 1982:323.)

Freud meen oseaniese gevoelens tree na vore wanneer die id oorneem en die persoon agteruitgaan. Hy bestempel dit dus as patologies (Steele, 1982:323). Jung aanvaar nie dat so iets patologies is nie, maar erken dat daar as gevolg daarvan ' $n$ verskuiwing in die psige plaasvind. Jung glo daaraan omdat hy dit self ervaar het en meen só ' $n$ mistieke ervaring is openbarend van wat in die onbewuste aangaan. Enige insigte vanuit die onbewuste kan net help om die "self" beter te verstaan (Steele, 1982:323). Dit kom neer op 'n grondliggende meningsverskil tussen Freud en Jung se definisies van simbole. Jung sien simbole vanuit die "kollektiewe" onbewuste (wat dit universeel maak), terwyl Freud van die "persoonlike" onbewuste praat, wat die ervaring eie aan 'n individu maak. Vir Freud is dit 'n simbool wat alleen deur die persoon interpreteer kan word. Jung sien dit egter as 'n "teken" (Stevens, 1994:108), wat per definisie universeel is om betekenisdraend te wees. Jung se teorieë is dus die geskikste vir hierdie ondersoek om drie vroue se oseaniese ervaring van nader te beskou.

$\mathrm{Na}$ aanleiding van Jung se uitspraak: "The mother archetype encompasses the entire unconscious: all creation and destruction, life as well as death" (Vermaak, 1988:20), kan 'n mens sê dat Milner se pasiënt dus gevoelens het wat universeel is, want haar drang na die oseaan dui op 'n drang na die groot moeder wat lewe gee en neem, wat bly kan maak en met vrees kan vul.

\subsection{Oseaanbelewenis en Jonker}

Jonker se "Swanger vrou" (Jonker, 1994:48) het parallelle met die oseaniese ervaring. 
Ek lê onder die kors van die nag singend, opgekrul in die riool, singend, en my nageslag lê in die water.

Ek speel ek is kind:

5 appelliefies, appelliefies en heide, koekmakrankas, anys, en die paddavis gly in die slym in die stroom, in my liggaam

10 my skuimwit gestalte; maar riool o riool my nageslag lê in die water.

Nóg singend vliesrooi ons bloedlied, ek en my gister,

15 my gister hang onder my hart, my kalkoentjie, my wiegende wêreld, en my hart wat sing soos 'n besie my besie-hart sing soos 'n besie; maar riool o riool,

20 my nageslag lê in die water.

Ek speel ek is bly: kyk wáár spat die vuurvlieg! die maanskyf, 'n nat snoet wat beef maar met die môre, die hinkende vroedvrou

25 koulik en grys op die skuiwende heuwels stoot ek jou uit deur die kors in die daglig, o treurende uil, groot uil van die daglig, los van my skoot maar besmeer met my trane besmeer

30 en besmet met verdriet.

Riool o riool, ek lê bewend singend, hoe anders as bewend met my nageslag onder jou water ...?

Die ek-spreker praat van haar "skuimwit gestalte" (r. 10), wat aan die skuimerige beeld van golwe herinner, asof sy self 'n brander geword het wat op die strand uitspoel. 'n Mens is egter onseker oor wie die "ek" is. Driesse (1971:45-46) stel dit so: "... [die] moontlikheid is natuurlik dat daar 'n mate van sielkundige identifikasie van die verwagtende moeder met die ongebore kind plaasvind, waarin sy haar feitlik geheel en al met die baba vereenselwig, in sy voorgeboortelike milieu". Wanneer dit in verband gebring word met Jon- 
ker se verlange na kindwees, na die oseaan asook "ek lê bewend singend" (r. 32), is daar 'n mate van ambivalensie. Indien "bewend" na vrees verwys, is sy bang om weer kind te wees, of weer een met haar moeder/die oseaan te wees. Net soos Milner se pasiënt vrees sy die geboorte, want nou is die nageslag nie "in" die water nie, maar "onder jou" water (vasgedruk?). Het die gedagte daaraan om self moeder te word Jonker aan haar eie ma laat dink? Dit is asof sy wil aandui haar verlede sleep haar hart ondertoe (r. 15), na haar verlede as gevolg van die feit dat haar ma so jonk oorlede is. Dit is 'n gedagte wat haar bly kan maak, omdat sy so naby aan haar ma voel, maar terselfdertyd kan dit haar melancholies maak.

lets waarmee Jonker 'n stryd gevoer het, is dat haar ma haar maklik kon aborteer het nadat sy van Abraham Jonker af weg is (Van der Merwe, 2006:239). Miskien is dit waarop die woordjie "riool" (r. 2, 11, 19, 31) sinspeel: dat afstand van die kind gedoen is en dat Jonker haarself daarmee identifiseer. Dit kon ook beïnvloed wees deur Uys Krige se vertaling van "La dernière nuit" (Die laaste nag), wat sy help tik het. Hiervolgens het "die armes ... hul brood in die riool vergaar" (r. 32), waarna "hulle" nie meer "bang" was nie (r. 34). As 'n mens dus deur die riool verswelg word, sal die vrees verdwyn.

Reël 10 bring die Griekse mite van Afrodite na vore. Afrodite het haar naam van aphros gekry, wat skuim beteken. Volgens die legende het Kronos, Uranus se seun, sy pa se genitalieë in die see gegooi. Dit het erg geskuim en Afrodite is hieruit gebore (Graves, 1992:49). Sy is baie lank as die seegodin aanbid, alhoewel sy ook as die godin van liefde en vrugbaarheid bekendgestaan het. Hierdie agtergrond en die feit dat Jonker hier van 'n "skuimwit gestalte" praat, maak parallelle met hierdie mitiese figuur of argetipe moontlik. Jonker herken (onbewustelik) haar argetipiese groot moeder in "Swanger vrou"; sy identifiseer haarself dus met die argetipiese beeld.

\subsection{Oseaanbelewenis en Boye}

Boye vereenselwig op verskillende maniere kennis en prag met die see. Uit een van haar gedigte, "Knowledge" (Boye, 1994:131), blyk dit op 'n interessante wyse: 
All the cautious ones with long nets meet with the sea's giant laughter.

Friends, what do you seek on the shore?

Knowledge can never be captured,

can never be owned.

But if, straight as a drop, you fall into the sea to dissolve, ready for any transformation -

then you will awake with mother-of-pearl skin

10 and green eyes

on meadows where the sea's horses graze and be knowledge.

Die "perlemoen-vel" en "groen oë" kan ewenwel 'n soort Afrodite wees: 'n figuur wat die ek-spreker met kennis uit die see gevul het. Dit word egter genoem met die wete dat vereenselwiging met die see (lewe) ook dood beteken (om "opgelos" te word/verdrinking). In reël 8 noem sy dit 'n "transformasie" - asof 'n "nuwe" self uit die see gebore kan word. Die see se lag (personifikasie) in reël 2 is klaarblyklik nie gulhartig nie, maar spottend. Dit word deur die vraag wat daarop volg, geskep, want die see weet: 'n lewe moet eers doodgaan voordat dit deel kan word van die see of kennis daaruit kan bekom.

By die lees van Boye se "Sea prayer" (Boye, 1994:134) ontstaan die vraag of sy met 'n kennis van Jungiaanse sielkunde geskryf het, aangesien sy self die primordiale daarin noem.

\section{Sea prayer}

Sea swell, come washing,

let me taste that sound's round, salty flow,

the sound that was given me

as primordial name aeons and aeons ago!

5 Words that no mortal

lips can tell

lie hidden

in the fresh, cold swell.

Long, too long

10 I starved on human words too easily told.

I want to rise up,

I want to satisfy my mouth at my mother's board.

Like a child in loathing's remorse

lost far away to roam,

15 I turn hungrily round 
to the songs of my home.

Let me drink

the speech of speech from a dull roar that never abates.

Let me clear

20 to your resting depth of light that creates.

Within soul and spirit

I hear your song.

Rise in my blood, and flower

In my tongue!

In strofe 1 vra sy dat die see moet kom om haar te was, om haar die klank te gee wat so lank gelede gegee is dat dit primordiaal, of deel van die kollektiewe onbewuste, geword het. Dit het woorde verloor en het bloot 'n simbool vir haar geword (r. 5-6): "Words that no mortal / lips can tell." Die ek-spreker het aan menslike woorde verhonger (r. 10) en verlang na "my mother's board", wat hier as die see verstaan moet word. Jung se omskrywing van die simbool van die see as groot moeder kan nie duideliker gestel word nie. Die laaste strofe is 'n klaarblyklike wens na die lewe in die see/onbewuste wat liggaamlike dood tot gevolg sal hê.

\subsection{Oseaanbelewenis en Plath}

Daar moet op gewys word dat die versinnebeelding van 'n argetipiese figuur, soos die moeder, nié op die persoonlike moeder geskoei is nie. Die argetipe is dikwels verskrikliker of aantrekliker as die gemiddelde menslike vrou (Vermaak, 1988:20). In Plath se geval lê die klem op die verskriklike eerder as die aantreklike, soos wat die geval is by Boye en Jonker. Plath se "Medusa" (Plath, 1981:224) is 'n goeie voorbeeld hiervan:

\section{Medusa}

Off that landspit of stony mouth-plugs,

Eyes rolled by white sticks,

Ears cupping the sea's incoherences,

You house your unnerving head - God-ball,

5 Lens of mercies,

Your stooges

Plying their wild cells in my keel's shadow,

Pushing by like hearts,

Red stigmata at the very center,

10 Riding the rip tide to the nearest point of departure, 
Dragging their Jesus hair.

Did I escape, I wonder?

My mind winds to you

Old barnacled umbilicus, Atlantic cable,

15 Keeping itself, it seems, in a state of miraculous repair.

In any case, you are always there,

Tremulous breath at the end of my line,

Curve of water upleaping

To my water rod, dazzling and grateful,

20 Touching and sucking.

I didn't call you.

I didn't call you at all.

Nevertheless, nevertheless

You steamed to me over the sea,

25 Fat and red, a placenta

Paralysing the kicking lovers.

Cobra light

Squeezing the breath from the blood bells

Of the fuchsia. I could draw no breath,

30 Dead and moneyless,

Overexposed, like an X-ray.

Who do you think you are?

A Communion wafer? Blubbery Mary?

I shall take no bite of your body,

35 Bottle in which I live,

Ghastly Vatican.

I am sick to death of hot salt.

Green as eunuchs, your wishes

Hiss at my sins

40 Off, off, eely tentacle!

There is nothing between us.

Medusa was eens op 'n tyd 'n aantreklike vrou, maar nadat sy by Poseidon geslaap het, het Athene haar verander sodat sy kloue, massiewe tande, glurende oë, 'n uithangtong en slanghare gekry het (Graves, 1992:127, 239). Een blik van die Medusa het mans in klip laat verander. Dit is die beeld wat Plath as 'n moeder voorstel. Die argetipe word egter soos volg na haar werklike moeder herlei:

My mind winds to you

Old barnacled umbilicus, Atlantic cable, 
Die wetenskaplike naam vir 'n medusa-seekwal is Aurelia aulita. Dit sinspeel klaarblyklik op Plath se ma, Aurelia. Hierdie seekwal word soms as melkerig wit en maanagtig beskryf (Lane, 1979:98). Die maan speel simbolies ook die rol van die moeder volgens Jung (1956:233; Vermaak, 1988:25). Hierbenewens is die Atlantic cable, 'n oseaniese/telefoniese verbinding tussen Amerika (waar Aurelia gewoon het) en Engeland (waar Plath gewoon het) 'n goeie beskrywing spesifiek vir Plath se ma. Die afstand tussen hierdie twee vroue word deur die naelstring (umbilicus) verkort tot die litteken wat Plath op haar maag dra (Lane, 1979:101). 'n Verbintenis wat Plath nie wil hê nie volgens strofe 5 en die laaste reël. Die ek-spreker se ambivalensie hieroor word in reël 19 duidelik, aangesien die beeld van 'n watersoeker se staf geskep word - sy soek wel en juis nié die water/moeder nie.

\section{Verdrinking in die see}

'n Insiggewende jeuggedig van Jonker, "Skrik" (Jonker, 1994:151), word aangehaal:

Jy is

'n rustelose see;

dis snaaks hoe jou liefde

' $n$ vrees is; ek is bang

5 As jy stort en styg om my heen

Tot ek vlug

Oor die sand

Van die bewende waterkant heen.

Jou woord is ' $\mathrm{n}$ klotsende brander

10 en die skuim jou wit trots

Maar wat gebeur en verander

In die donkergroen diep van jou bors?

Die personifikasie van die see deur die persoonlike voornaamwoord "Jy" (met hoofletter) skep 'n gemoedelike atmosfeer waarin die spreker en die aangesprokene (die see) kan verkeer. Die "rusteloosheid" van die see kan betrekking hê op óf die aanlokkende aard van die see, soos die "galme van die branders" ("Gesprek op 'n hotelterras"; Jonker, 1994:101), óf dit kan op die ek-spreker se interpretasie dui dat die see rusteloos is en dat sy die vermoë het om dit tot rus te bring (Gertenbach, 1997). Die liefde wat in reël 3 genoem word en die gerusstelling van die bors (r. 12), kan verbind word met die oseaniese belewenis soos by Boye. Die kleur, donkergroen, wat lewe en dood ter sprake bring, is in hierdie opsig belangrik. Of vind sy dalk in Afrodite se omhelsing troos? In die tipografie van die 
eerste strofe lyk dit asof die see se "stort en styg" (r. 5) uitreik om die ek-spreker vas te gryp en haar toe te vou, al is sy bang. Reëls 5 en 8 is soos arms van water wat die vlugtende ek-spreker op die sand wil vasdruk. Van Wyk (1983:15) wys ook daarop dat Jonker telkens die beelde van die see met jeug en kindwees assosieer. Hy voer dit verder deur te beweer dat dit ' $n$ verlange na die geborgenheid van die baarmoeder is.

Soortgelyke gevoelens van geborgenheid, maar ook vrees, kom na vore in Plath se "Departure" (1981:51):

\section{Departure}

The figs on the fig tree in the yard are green;

Green, also, the grapes on the green vine

Shading the brickred porch tiles.

The money's run out.

5 How nature, sensing this, compounds her bitters.

Ungifted, ungrieved, our leavetaking.

The sun shines on unripe corn.

Cats play in the stalks.

Retrospect shall not soften such penury -

10 Sun's brass, the moon's steely patinas,

The leaden slag of the world -

But always expose

The scraggy rock spit shielding the town's blue bay

Against which the brunt of outer sea

15 Beats, is brutal endlessly.

Gull-fouled, a stone hut

Bares its low lintel to corroding weathers:

Across the jut of ochreous rock

Goats shamble, morose, rank-haired,

20 To lick the sea-salt.

In die eerste instansie is die see 'n skadelose "blue bay", maar tog ook iets waarteen die dorpie beskerm moet word. Dit is dus gelyktydig aantreklik, maar ook rusteloos soos in die geval van "Skrik" of "Ek betreur jou" (Jonker, 1994:107): "My hand van stof / kan die rotse nie trotseer nie" (en verdrink dus). Volgens Jung (1959:18) is water die belangrikste simbool vir die onbewuste. Dit kan enige vorm van water wees: 'n rivier, die see, 'n meer, selfs 'n glas water. Plath se opinie van die moeder/onbewuste as "brutaal" tree weer 
hier na vore, derhalwe is 'n "rock spit" nodig om die dorpie (of haarself) te beskerm.

Jonker se "Donker stroom" (Jonker, 1994:104) sluit deur middel van sy titel by Eugène N. Marais se "Diep rivier" (Marais, 1936:58) aan waar die rivier se "omhelsing" al die ek-spreker se smart stopsit. Haar "groen stroom" is net so "vol lewe" soos Marais se diep, druisende, koue water. Die ek-spreker kan nie met enigiets in Jonker se gedig praat waarin die son kyk nie, die "paddavissies is te skugter" en hulle toekoms "te onseker" (r. 8):

Stroom waarin die donker

net die donker sien

met jou kan ek praat

ek ken jou beter.

Dit is nie die "staal en goud" (van Marais se gedig) of die son waarna hierdie ek-sprekers verlang nie: dit is die donkerte of nigredo van die donker stroom of die onbewuste. Dít is wat hulle beter ken.

In haar "To the sea" (Boye, 1994:62) maak Boye van dieselfde "omhelsing" melding. Beskou 'n mens die water as die onbewuste en indien die ek-spreker homself hierin doop, sou die smart daar ophou en op 'n nuwe begin uitloop, soos die alchemistiese nigredo wat nat moet word voordat dit suiwer/heel kan wees. Hierdie beeld word bespreek:

\section{To the sea}

O sea, sea,

how strong that drink you brew!

Your great cold

is holy purification clear.

5 Your light-embrace

is cool health for human children, for us who love healing.

For you, sea,

beaming soft, roaring hard

false, and faithful always,

10 are a beautiful simile for beautiful things:

for the bold heart's salt-foamed way in the world.

Plath skryf oor 'n donker stroom in Lorelei (Plath, 1981:94). Die Lorelei is ' $n$ groot klip aan die wal van die Rynrivier. Volgens legende was dit 'n sirene wat vissermanne na hulle dood gelei het. Dit is wat oorgebly het nadat 'n aantreklike meisie in die rivier selfmoord gepleeg het weens 'n oneerlike minnaar. Blykbaar skep die klip 'n eggo 
wat verband hou met hierdie legende. In Plath se gedig lui die laaste strofe:

$O$ river, I see drifting

Deep in your flux of silver

Those great goddesses of peace.

Stone, stone, ferry me down there.

Die tweede laaste reël dui ook aan, soos in "Donker stroom", dat die ek-spreker bekend is met die argetipes (goddesses of peace) in haar onbewuste (in die rivier). Dit is ook insiggewend dat die lorelei 'n soort modderpaling is (Lane, 1979:109), soos die vorme wat in reël 9 na haar toe opswem en vir die ek-spreker aantreklik is. Albei bogenoemde gedigte beeld die ek-spreker se drang na verdrinking uit.

Jonker se "Ontvlugting" (Jonker, 1994:17) word afgesluit met die bekende reëls: "My lyk lê uitgespoel in wier en gras / op al die plekke waar ons eenmaal was". Dit kom ook voor in Boye se "The sea" (Boye, 1994:107) asook in Plath se "Contusion" (Plath, 1981:271):

\section{The Sea}

Salt, bitter salt

is the sea, and clear and cold.

In the depths much moulders away, but the sea cleanses all.

5 Wild, prey-beast wild is the surf's glittering leap, but no human thoughts are high as the song of the deep.

Strong, eternal and strong

10 is the waves' immense train, and strong with the eternal sea

each wave soft, transient.

Though the sea asks blood of her man, give your life to the sea.

15 At last, deep in the depths, none attains a rest like he.

\section{Contusion}

Color floods to the spot, dull purple.

The rest of the body is all washed out,

The color of pearl. 


\section{In a pit of rock \\ 5 The sea sucks obsessively, \\ One hollow the whole sea's pivot.}

The size of a fly,

The doom mark

Crawls down the wall.

10 The heart shuts,

The sea slides back,

The mirrors are sheeted.

Die eerste strofe van laasgenoemde gedig is die beskrywing van 'n lyk, "as pearl", soos in Boye se "Knowledge": "you will awake with mother-of-pearl skin" (Boye, 1994:131). Bygelowiges bedek spieëls met wit lakens wanneer daar ' $n$ sterfte is om te keer dat 'n mens die oorledene oor jou skouer sien loer en om seker te maak dat die spook tot rus kom (Opie \& Tatem, 1989:250). Al word dit nie hier pertinent uitgespel nie, is "Contusion" die ek-spreker se beskrywing van 'n lyk wat op die strand uitgespoel het. Die feit dat "The sea sucks obsessively" maak dit duidelik dat die ek-spreker hierdie beeld nie uit die onbewuste kan verban nie.

\section{Gevolgtrekking: doop as nuwe lewe}

"As the alchemists strove to produce an incorruptible 'glorified body', they would, if they were successful, attain that state in the albedo, where the body became spotless and no longer subject to decay" (Jung, 1963:238). Hierdie perfekte pêrel kom eers tot stand ná coniunctio wat miskien kan lei tot die nigredo (die skaduwee) en hierna "the philosophers shed tears over the stone ... so that ... it loses its blackness and becomes white as a pearl" (Jung, 1967:331). Die rede vir die trane kom waarskynlik vanuit die alchemiste se kennis van die kerk van Kolossense 2:12: "Dit het by die doop gebeur deurdat julle toe saam met Hom begrawe is." Vandaar die idee dat 'n mens se sondes deur die doop weggewas word. Die water vorm as sodanig ' $n$ tussenganger tussen die lewe en die dood (Steenberg, 1993:457). Wanneer 'n persoon vir die eerste keer in aanraking kom met die gevaarlike onbewuste, het dit trane (wat helend is) tot gevolg (Hambidge, 2001). Jung se woorde: "That saving flood is both your sepulchre and your mother" (Jung, 1963:236), word in die voorafgaande gedigte geïllustreer. Die water smelt weer met die dood (sepulchre $=$ graf) en die moeder saam. Die konnotasie van die reën in "Verlore stad" (Jonker, 1994:52) is dié van suiwering (Van Wyk, 2000). 


\section{Verlore stad}

In die reën wat verby is ver dag en verlore stad van akkers van duiwe vol dagbreek

was my hande die ene eekhorinkie vinnig sku maar voorbereid ver dag en verlore stad

deur al die mense het jy gekom met 'n eenvoudige glimlag soos van 'n lang reis

10 en die reën wat verby is het hom verwarm aan my lyf die reën van rook en oker

wat ruik na jou hande skoongewas na warm duiwe en die oop

15 oranje papawer van die lug

Die aangesprokene in hierdie gedig kan op Jonker se ma dui, waar die lang reis van reël 9 haar vertrek (die "verlore stad" van r. 2 en 6) uit die lewe en haar terugkeer kan beteken - dit is veral gesien vanuit die perspektief dat Jung stede of plekke wat met eerbied bejeën word as moeder-simbole tipeer (Jung, 1959:81). Die ek-spreker het haar op hierdie koms voorberei (r. 5) asof sy geweet het wat volgende gaan gebeur. Dit sluit aan by die idee van 'n eekhorinkie (r. 4) wat die indruk skep van ' $n$ wese wat alles wil insamel, alles wil bymekaarmaak wat die reën (in die vorm van haar moeder) ook al bring. So 'n interpretasie sou die ek-spreker se dood inlei indien die gestorwene gekom het om haar dogter te kom haal.

Sielkundig gesproke sou die resultaat van die alchemiste se werk op die bewustelike integrasie van die onbewuste uitloop (Jung, 1963: 238). ' $n$ Mens is geneig om onaangename aspekte van die self in die onbewuste te laat verdwyn. Dit is waarom hierdie proses pynlik kan wees - vandaar die vrees vir verdrinking. 'n Mens wonder of jy ooit weer uit die water/onbewuste/moeder sal kan opstaan nadat jy daar ondersoek ingestel het. 'n Mens kan ook jou vrees oorkom en 'n "kosbare pêrel" word, volgens die simboliek van die alchemiste. Hierdie simboliek kom herhaaldelik in die bespreekte gedigte voor: "To the sea" (Boye, 1994:62): "Your great cold / is holy purification clear"; "The sea" (Boye, 1994:107): "but the sea cleanses all"; "Sea prayer" (Boye, 1994:134): "Sea swell come washing ..."; "Verlore 
stad" (Jonker, 1994:52): "die reën ... wat ruik na jou hande skoongewas"; "Lorelei" (Plath, 1981:94): "They sing / Of a world more full and clear"; "Contusion" (Plath, 1981:271): "The rest of the body is all washed out / The color of pearl." In die gedigte waarop daar nie direk gewys word nie, soos "Swanger vrou" (Jonker, 1994:48), kom die betekenis van die hele gedig op dieselfde neer. Hierdie gedig hoef byvoorbeeld nie die beskrywing te wees van die geboorte van Simone nie, maar van Jonker self: "in my liggaam / my skuimwit gestalte" (r. 9-10). Die "skuimwit gestalte" (wat "myne" is: "ek en my gister", nie "ek en my dogter" nie), is die een wat uit dieselfde liggaam gebore word, en dit is "met trane besmeer" (r. 29). Aan die hand van Freud bly die betekenis van die gedig duister. Jung se teorie open dit egter na universele beelde wat meer diepte daaraan verleen.

Plath se verwysing na die nagmaalsoblietjie ("Medusa", r. 33) dui ook op 'n drang na reiniging. Maar by Plath is die argetipiese moederbeeld nie vriendelik nie. Die water moet eers verwyder word sodat daar net nog sout oorbly: "To lick the sea-salt" ("Departure", laaste reël). Die ek-spreker in Plath se gedigte kan nie in die see verdrink nie, want "I am sick to death of hot salt" ("Medusa", r. 37). Dit maak dit vir haar onmoontlik om rus by die groot moeder te vind, om nie eens van trane/huil te praat nie.

Jung bestempel die dood self as 'n terugkeer na die baarmoeder: "death in its cold embrace is the maternal womb, just as the sea devours the sun but brings it forth again" (Jung, 1956:218, 238). Die drang na eenwording met die see is dus nie morbied daarin dat die digters blyk dood te wil wees nie. Inteendeel, hulle smag na 'n dieper kennis van die onbewuste, na die self. Dit is 'n gesonde drang wat hulle misverstaan het omdat hulle dit nie as simbool geïnterpreteer het nie en letterlik selfmoord gepleeg het.

\section{Geraadpleegde bronne}

BOYE, K. 1994. Complete poems. Translated by David McDuff. New Castle upon Tyne: Bloodaxe Books.

DRIESSE, O.E. 1971. Die poësie van Ingrid Jonker. Kaapstad: Universiteit van Kaapstad. (M.A.-tesis.)

GERTENBACH, I. 1997. Die skryf van poësie as uiting van 'n inherente skeppingsbehoefte met verwysing na Ingrid Jonker. Pietermaritzburg: Universiteit van Kwazulu-Natal. (B.A. Hons.-skripsie.)

GRAVES, R. 1992. The Greek myths. Vol 1. Middlesex: Penguin.

HAMBIDGE, J. 2001. Gender en die primordiale. Stilet, (13)3.

JONKER, I. 1994. Versamelde werke. Kaapstad: Human \& Rousseau. 
JUNG, C.G. 1956. Symbols of transformation. Vol. 5. London: Routledge \& Kegan Paul. (Collected works of C.G. Jung.)

JUNG, C.G. 1959. The archetypes and the collective unconscious. Vol. 9, part 1. London: Routledge \& Kegan Paul. (Collected works of C.G. Jung.)

JUNG, C.G. 1963. Mysterium coniunctionis: an inquiry into the separation and synthesis of psychic opposites in alchemy. Vol. 14. London: Routledge \& Kegan Paul. (Collected works of C.G. Jung.)

JUNG, C.G. 1967. Alchemical studies. Vol. 13. London: Routledge \& Kegan Paul. (Collected works of C.G. Jung.)

LANE, G. 1979. Sylvia Plath: new views on the poetry. Baltimore: Johns Hopkins University Press.

MARAIS, E.N. 1936. Versamelde gedigte. Pretoria: Van Schaik.

MILNER, M. 1988 The hands of the living God: an account of a psycho-analytic treatment. London: Virago.

OPIE, I. \& TATEM, M. 1989. A dictionary of superstitions. Oxford: Oxford University Press.

PLATH, S. 1981. Collected poems. London: Faber \& Faber.

STEELE, R.S. 1982. Freud and Jung: conflicts of interpretation. London: Routledge \& Kegan Paul.

STEENBERG, D.H. 1993. Simbolisme in die Afrikaanse digterlike tradisie. Potchefstroom: $\mathrm{PU}$ vir $\mathrm{CHO}$.

STEVENS, A. 1994. Jung: a very short introduction. Oxford: Oxford University Press.

STRACHEY, J., FREUD, A., STRACEY, A. \& TYSON, A. 1961. The standard edition of the complete psychological works of Sigmund Freud. Vol. 21. London: Hogarth.

VAN DER MERWE, L.M. 2006 Gesprekke oor Ingrid Jonker. Hermanus: Hemel en see boeke.

VAN WYK, J. 1983. 'n Ondersoek na die poësie en lewe van Ingrid Jonker, 1. Ensovoort, 3:1.

VAN WYK, J. 1984. 'n Ondersoek na die poësie en lewe van Ingrid Jonker, 2. Ensovoort, 4:2.

VAN WYK, J. 2000. Die aangesprokene in die Ingrid Jonker-oeuvre. Stilet, (12)2.

VERMAAK, J. 1988. Jung's concept of the mother archetype and its influence on women's lives: a literature review. Stellenbosch: University of Stellenbosch. (M.Ed.-dissertation.)

\section{Kernbegrippe:}

argetipes: moederargetipe

Boye, Karin

Freud

Jonker, Ingrid

Jung

oseaanbelewenis

Plath, Sylvia

seesimbool 


\section{Key concepts:}

archetypes: mother archetype

Boye, Karin

Freud

Jonker, Ingrid

Jung

oceanic feeling

oceanic symbolism

Plath, Sylvia 
